Article

\title{
Livelihood Implications and Perceptions of Large Scale Investment in Natural Resources for Conservation and Carbon Sequestration: Empirical Evidence from REDD+ in Vietnam
}

\author{
Mucahid Mustafa Bayrak ${ }^{1, *}$ and Lawal Mohammed Marafa ${ }^{2}$ \\ 1 Department of Human Geography and Spatial Planning, Faculty of Geosciences, Utrecht University, \\ P.O. Box $80.115,3508$ TC, Utrecht, The Netherlands \\ 2 Department of Geography and Resource Management, The Chinese University of Hong Kong, \\ Hong Kong SAR, China; lmmarafa@cuhk.edu.hk \\ * Correspondence: m.m.bayrak@uu.nl or mmbayrak@link.cuhk.edu.hk; Tel.: +31-30-253-1399
}

Received: 29 August 2017; Accepted: 28 September 2017; Published: 5 October 2017

\begin{abstract}
The complex relationship between local development and current large scale investments in natural resources in the Global South for the purpose of conservation and carbon sequestration is not fully understood yet. The Reducing Emissions from Deforestation and Forest Degradation programme (REDD+) is an example of such investment. This study examines the livelihood implications and perceptions of REDD+ among indigenous and forest-dependent communities in the Central Highlands of Vietnam. A systems-based livelihood survey has been conducted with two communities affected by REDD+ $(n=102)$-Kala Tonggu village (participating in UN-REDD, a multilateral programme) and Hieu commune (participating in a REDD+ project of Fauna and Flora International). The positive effects of REDD+ included: introduction of community-based forest management; shifting power relations in favour of local communities; communities receiving financial benefits for forest monitoring; and positive community perceptions on REDD+. The negative impacts concerned: more restricted access to the natural forest; raising false expectations on the financial benefits of REDD+; increasing risks of food insecurity; exclusion of customary institutions and forest classifications; and lack of livelihood alternatives in dealing with changing socio-ecological conditions. Based on the findings of this study, we argue that REDD+ implementation needs to incorporate the temporality and dynamics of community livelihoods, power relations, and customary and formal socio-ecological systems more comprehensively. This to ultimately achieve inclusive local development and effective conservation of global forest commons.
\end{abstract}

Keywords: REDD+; forest-dependent livelihood; socio-ecological system; Vietnam; global land rush; carbon sequestration; livelihood perception; climate action

\section{Introduction}

\subsection{Background of the Study}

Current knowledge on climate change shows that human civilisation has the capability to influence the environment at the scale of the Earth as a single, evolving planetary system. As a result, many experts declared that Earth has entered a new geological epoch-the Anthropocene [1]. Sustainable Development Goal 13 (SDG 13), climate action, therefore starts with the premise that "climate change is now affecting every country on every continent. It is disrupting national economies and affecting lives, costing people, communities and countries dearly today and even more tomorrow" [2]. Clearly, the global community is responsible to deal with the negative effects of climate change as 
it affects all domains of our lives, such as our economy, environment and well-being. The world community's pledge to combat climate change led to the adoption of the Paris Agreement in 2016, and the commitment to participate in the United Nations Framework Convention on Climate Change's (UNFCCC) Reducing Emissions from Deforestation and Forest Degradation programme (REDD+) in 2007.

REDD+ is a global investment by the Global North in (tropical) forestland in the South as a means to sequestrate carbon in exchange for monetary and in-kind benefits. These benefits include payment for carbon credits, knowledge and technology transfer, and general capacity enhancement of developing countries [3,4]. REDD+ reflects, somewhat paradoxically, the growing dependence of the Global North on the South to preserve, maintain or repair the global environment [5]. REDD+ is supported by various multilateral organisations (such as United Nations (UN) agencies and the World Bank) as well as Non-Governmental Organisations (NGOs) and government bodies. Currently, REDD+ is not yet functioning on a national level. However, REDD+ did contribute to a changing discourse on world's (tropical) forest ecosystems as they are now presented as global instead of local commons [6,7]. This introduced various opportunities but also challenges to biodiversity conservation and livelihood development of local communities depending on forests [8].

The relationship between globalisation, the environment and (local) development can be characterised as "fuzzy" at best [7]. The negative effects of globalisation on the environment are traditionally well-documented [9], but the dialectic and complex relationships among these three domains are still subjected to heated debates. This ranges from neoliberal and technocratic solutions (e.g., geo-engineering and the planetary boundary approach) to radical or ecocentric environmentalism (e.g., the Gaia hypothesis and deep ecology) [1]. Nonetheless, these heated debates did not prevent global actors from massively investing in land in the Global South for the purpose of conservation, tourism, agribusiness, biofuel and/or REDD+, signifying a new trend in globalisation and development [7,10]. This development trend, which began in 2007, has been coined as the "global land rush" [7]. This rush resulted in complex and dramatic transformations of landscapes in the Global South, which have important implications for peoples' livelihoods and local development $[7,11-13]$. Natural resources, such as forest, water and land, which were once perceived as local assets of peoples' livelihoods have now entered the global market system as valuable commodities [14]. Within the context of REDD+, critics of this development trend highlight the associated risks of green grabbing (the appropriation of land and resources for environmental ends), potential conflicts due to displacements of local communities, competing land claims, exacerbating food insecurity and income inequality, and overall restructuring of local landscapes $[8,10,14,15]$. This study investigates the livelihood implications and perceptions of REDD+ among forest-dependent communities in Vietnam.

\subsection{Climate Change and Local Communities in Vietnam: Setting the Scene}

The Socialist Republic of Vietnam was chosen for this research for several reasons. First, Vietnam is a signatory to the UNFCCC (1994) and the Kyoto Protocol (2002), and the Socialist Republic ratified the Paris Agreement in 2016. Vietnam, having a forest cover of around $40 \%$, pledged to combat deforestation and forest degradation through various joint global efforts, including the Convention on Biological Diversity (CBD), the Convention on International Trade in Endangered Species of Wild Fauna and Flora (CITES) and Forest Law Enforcement, Governance and Trade (FLEGT). Vietnam is also one of the first countries to participate in REDD+. Second, Vietnam is considered as one of the countries to be severely affected by climate change. The nation is increasingly vulnerable to climate-related natural disasters such as typhoons, flooding and droughts, and is thus exploring ways to respond to climate change [16]. Lastly, Vietnam remains a largely agrarian society, with about $33.6 \%$ of its population living in urban areas in 2015 [17]. Vietnam has 53 officially recognised ethnic minority groups, accounting for $13.8 \%$ of the total population. Many of these groups are forest-dependent, poor, indigenous to the region, and to a great degree vulnerable to climate change $[16,18]$. Hence, 
Vietnam is a good case study to illustrate how global investments in REDD+ and forest commons affect forest-dependent livelihoods, biodiversity conservation, and local development.

\subsection{Aim and Outline of the Study}

Within the REDD+ debate, we argue that we need more empirical research "on the ground" to decipher how global investments actually restructure and interact with peoples' livelihoods. This includes both the livelihood implications and perceptions of local communities. To do this, livelihoods need to be studied in conjunction with the wider socio-economic and ecological context, policy environment, and translocal and global capital flows affecting them $[19,20]$. Two REDD+ programmes affecting local and indigenous communities in Vietnam's Central Highlands have been selected for this study. In both research sites, REDD+ mechanism have been implemented, but carbon payments are yet to happen at the time of writing this article. To what extent did REDD+ already change the livelihoods of affected households, and what were the expected livelihood benefits of REDD+? Furthermore, how did the community livelihoods change over the past two decades, especially in relation to REDD+? Thus, this study sought to understand the (future) interactions of REDD+ with forest-dependent livelihoods across time and space.

This article is structured as follows. Section 2 concerns the theoretical framework of this study. In this section, we construct a systems-based livelihoods framework in order to understand the livelihood implications and perceptions of REDD+ of local communities. Section 3 describes the methodology and research context of this study. It also deals with the forest governance context of Vietnam as well as the socio-economic characteristics of the research sites. Section 4 is the results section. The structure of this section is based on the components of the systems-based livelihoods framework. Lastly, Section 5 summarises the main findings of this empirical study, and provides insights, both theoretical and policy-related, for the current debate on REDD+, and the "global land rush" in more general. Section 5.2, the practical layer of the conclusion, provides policy recommendations related to REDD+ implementation among local communities. This could be utilized in future policymaking on REDD+ and other global investments in the forest commons.

\section{Theoretical Framework: Assessing Livelihood Implications and Perceptions}

The sustainable livelihoods approach has been an integral framework in the field of development geography since the 1990s. The most commonly used definition of a livelihood is the means of securing a living resulting from interactions between capabilities (as defined by Sen [21]), tangible assets (such as natural, physical and financial capitals) and intangible assets (human, social and cultural capitals) [22,23]. Carney [24] further states that a livelihood is sustainable when it can cope with and recover from stresses and shocks, and maintain its capabilities and assets. This should be both now and in the future, while not undermining the natural resource base [23-27].

The sustainable livelihoods approach has evolved since its conception in the 1990s-from perceiving households, being members of relatively homogenous communities, having access to various types of capital to translocal livelihood trajectories or pathways [28-30]. First, communities are no longer considered homogenous. Members of a community have different interests influenced by gender, class, ethnicity, religion, socioeconomic group or age [31-33]. Livelihood opportunities are not only governed by social relations, institutions and organisations, but the role of power has often proven to be an important explanatory variable [30]. Second, livelihood strategies should be seen as pathways and iterative processes $[20,29,34]$. Temporal dynamics of livelihood strategies are outcomes of learning processes, past experiences, and collective and individual desires. This means that livelihood strategies are continuously subjected to change, and should be regarded as dynamic and nonlinear [29]. In this regard, local and indigenous livelihood systems are continuously modified by both external (e.g., changing climatic and ecological conditions or integration into mainstream society) and internal drivers (e.g., personal desires or changing perceptions). Third, globalisation often results in translocal patterns of development. People are increasingly connected to other geographical areas 
through technological advancement, migration flows, and foreign investment. This has led to translocal livelihood strategies and an increasing importance of local and non-local networks and (capital) flows [13]. To summarise the key changes in livelihood theory, De Haan [30] describes livelihood trajectories as multi-layered phenomena. The first layer refers to one's capability or qualification to have access to a certain type of capital (e.g., a diploma to attend university or a loan to acquire land). The second layer concerns the power struggles surrounding livelihood opportunities and access to the various types of capital, whereas the third layer deals with underlying structures directing social behaviour.

The sustainable livelihoods approach has been applauded for its holistic and micro-level of analysis. However, there are increasing concerns that current livelihood studies are neither generalisable nor able to challenge existing theories [19]. Another concern with this approach is that it treats the socio-ecological context often as a black box. A comprehensive systems-perspective is therefore missing in this approach. Scholarship on resilience and Socio-Ecological Systems (SES) [35-40] could add a much needed systems-perspective to the sustainable livelihoods approach as it acknowledges that natural-resource dependent livelihoods are embedded in a particular SES. Based on ample empirical evidence and theories on the commons, Ostrom [36,41], Ostrom and Cox [38], and McGinnis [37] created a multilevel nested framework which enhances our understanding of the nonlinear, complex, cross-scalar and evolutionary dynamics of socio-ecological systems-the SES framework. Problems of overharvesting, environmental degradation, natural resource-based conflicts or green grabbing very rarely have a single cause; it often consists of multiple causes and drivers [36]. For this reason, it is important to approach these problems from a systems-based approach.

Anderies et al. [42] define a SES as the subset of social systems "in which some of the interdependent relationships among humans are mediated through interactions with biophysical and non-human biological units". A SES is furthermore composed of multiple subsystems and internal attributes within these subsystems. These subsystems are: resource systems (e.g., forests and grasslands, but could also include the built environment), resource units (e.g., wood, non-timber forest products, animals, etc.), actors (e.g., local communities, government institutions, NGOs, etc.) and governance systems (rules, grievance mechanism, governance structures, etc.). These four sub-systems, or first-tier components of the SES framework, operate and interact with each other in a specific socio-economic and ecological context. These interactions result in focal action situations in which specific socio-ecological outcomes follow. Each first-tier component consists of second, third, and $n$th tiered variables, and can therefore be expanded. For example, if the resource system is a forest, its second-tier variables include forest size, boundaries, system dynamics, storage capacity, and so on. Second-tier variables of actors include number of users, social capital, leadership, and knowledge or mental models of the SES. Within each ecosystem, there are multiple resource systems, such as forests, lakes, rivers, etc., and therefore each resource system has its own first-tier components and multiple-tier attributes [36,41].

Whereas the livelihood approach perceives households (as diverse as they are) as agents of change, the SES framework considers households as part of a system, namely one of the actors. Therefore, within the context of forest-dependent livelihoods and REDD+, both frameworks could strengthen and complement each other in several ways (Figure 1). We take the sustainable livelihoods approach and households' capabilities and access to different types of capitals as the entry point. The next step is to acknowledge that these households are situated in a socio-ecological context. Within a SES-system, multiple-tier and contextual attributes are interacting with each other through focal action situations in which socio-ecological outcomes follow, affecting both households and the natural resources they depend on. The double arrow between actors and governance systems in Figure 1 refers to the power relations, and hence the second layer as described by De Haan [30]. Moreover, it refers to households' access to social, cultural and human capital. The double arrow between resource systems and units, and actors illustrates the first layer, and concerns households' access to natural and physical capital. 
The socio-ecological context should be seen as the third layer, and deals with underlying systems and structures.

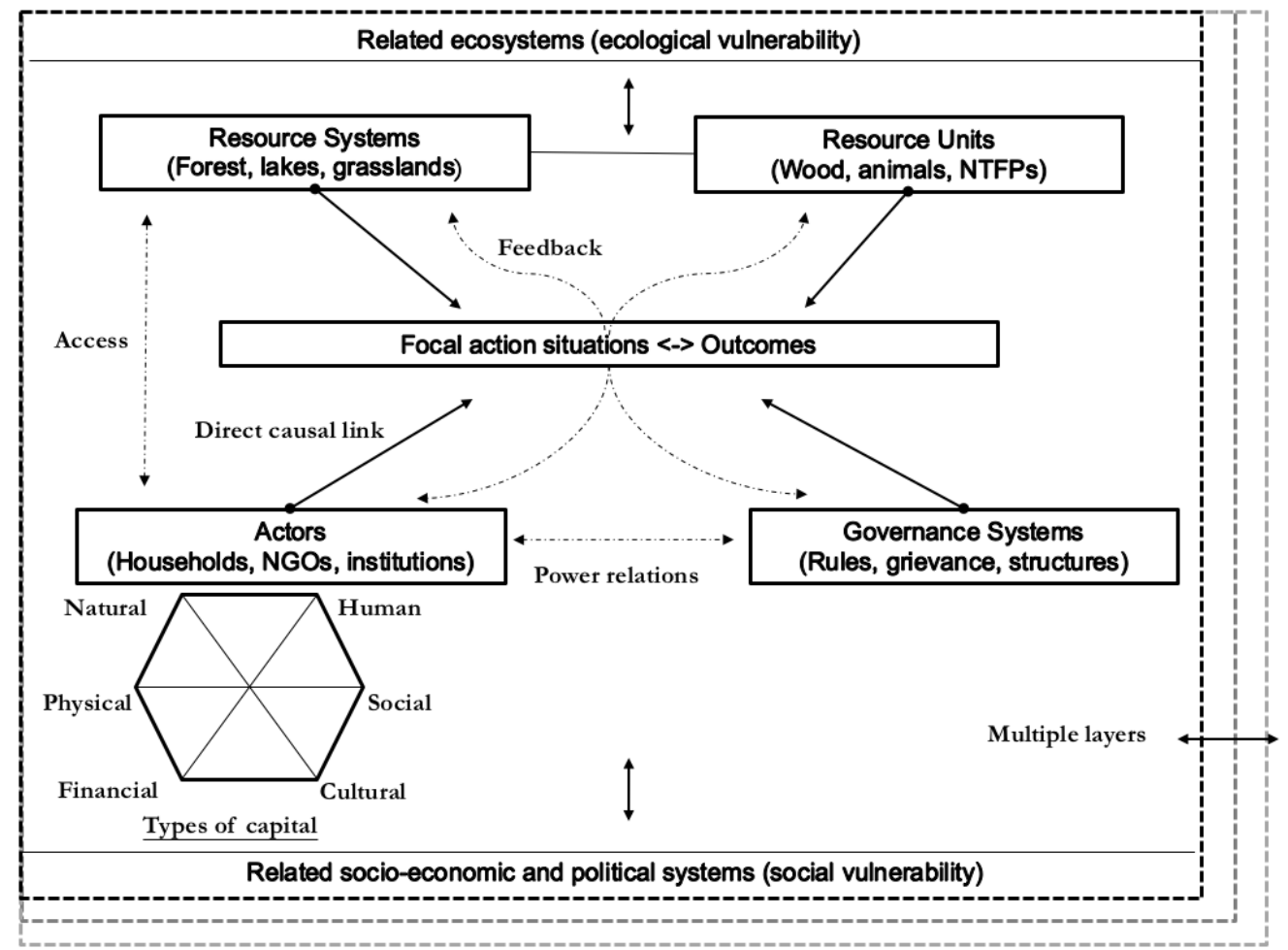

Figure 1. Systems-based livelihood framework [24,36-38].

\section{Research Context and Methods}

\subsection{Forest Governance and REDD+ in Vietnam}

Ever since the colonial period, forests have been an important domain of state control in Vietnam $[43,44]$. The Socialist Republic of Vietnam opened up during the late 1980s due to the Doi Moi, or opening-up, reforms, which transformed Vietnam into a socialist market-economy. This resulted in a change of the Socialist Republic's forest governance-from top down state-controlled management to forestland allocation and decentralisation to non-state actors, such as individual households, private organisations, and communities. As a result of the Forestland Allocation programme (FLA), these non-state actors received land use certificates (so-called Red Books) of patches of forestland for usually 50 years. Local households are able to invest in their allocated forestland, but they can also use it for commercial purposes, such as sell it, use it as collateral for loans, and conduct agroforestry. This should be in accordance with government policy. While communities are also able to receive Red Books, they can only use their forestland for Community-Based Forest Management (CBFM). Additionally, Green Books enable households and communities to be contracted to protect and conserve the forests or to plant trees. Vietnam has been involved in REDD+ readiness activities since 2008. Vietnam participates in the United Nations Collaborative Programme on Reducing Emissions from Deforestation and Forest Degradation in Developing Countries (UN-REDD) and the Forest Carbon Partnership Facility (FCPF) of the World Bank. Besides that, various NGOs have implemented REDD+ projects in Vietnam, such as Fauna and Flora International's REDD+ Community Carbon Pools Programme (FFI-REDD+) amongst other NGOs. Currently, REDD+ has not yet been implemented on a national level. Lastly, since 2011, Vietnam introduced a nation-wide Payment for Forest Environmental Services (PFES) programme and fund which allowed households to receive additional financial aids for forest protection [4,43-47]. 


\subsection{Selection Criteria for the Research Sites}

A multilateral and an NGO REDD+ project were selected to understand their essential differences in approaches to REDD+ implementation. To compare two different types of REDD+ schemes, the research sites had to be fairly similar in terms of social and livelihood characteristics. The following criteria were used in order to select the research sites. The site had to consist of an indigenous and forest-dependent community involved in farm and off-farm livelihood activities. Additionally, all members of the community had to be actively involved in REDD+ readiness activities, and the research site had to be accessible for research, e.g., the necessary government permits could be obtained. Fulfilling these selection criteria, two research sites in Vietnam's Central Highlands were selected for this research (Figure 2): Kala Tonggu village in Bao Thuan commune, Lam Dong province (hereinafter referred to as "Kala Tonggu") and Hieu commune in Kon Tum province ("Hieu"). Kala Tonggu has been involved in UN-REDD since 2010, whereas Hieu was targeted by FFI-REDD+ in 2011.

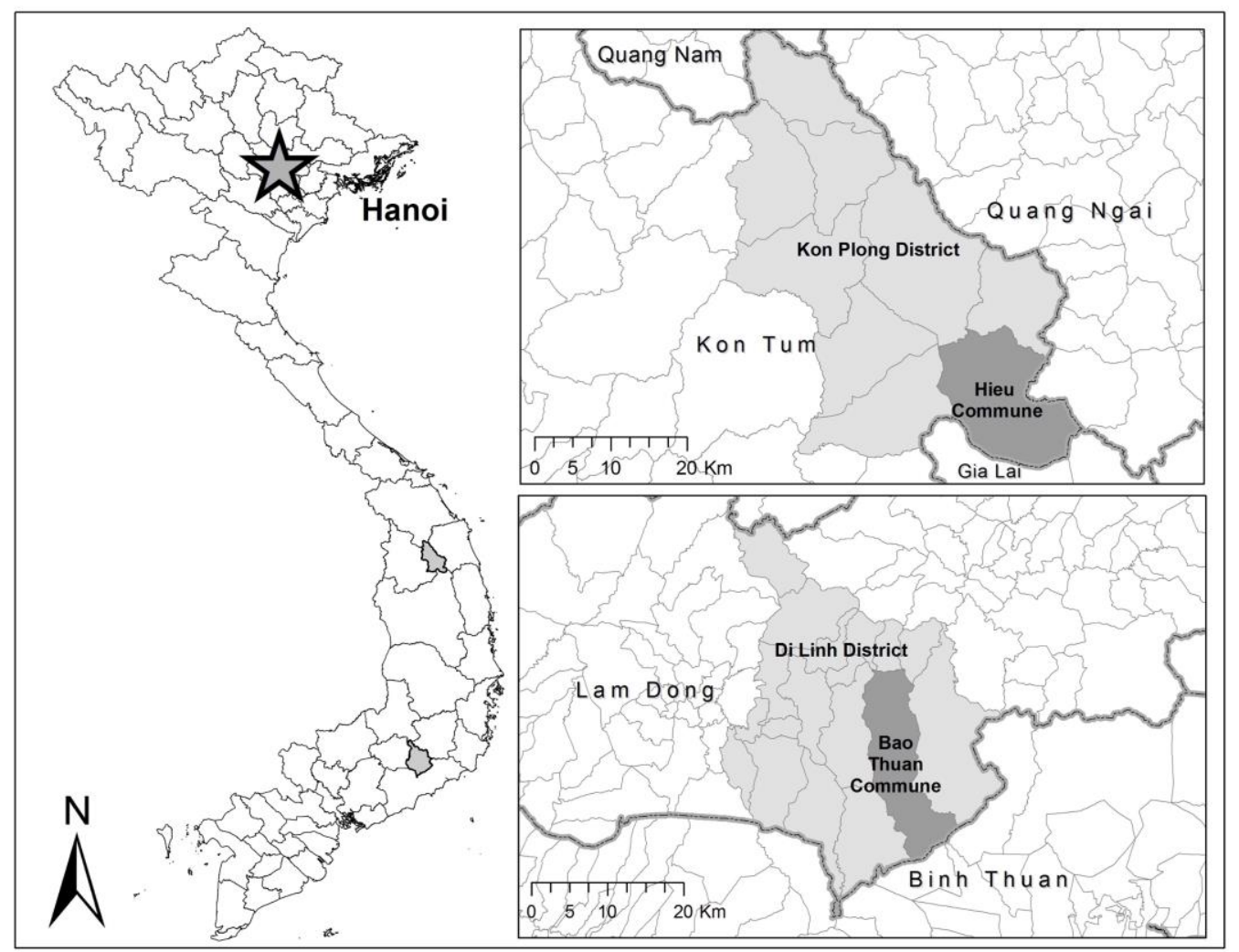

Figure 2. Location of research sites in Vietnam (Note: Kala Tonggu is located in Bao Thuan commune).

\subsection{Methodology and Operationalisation}

A systems-based livelihood survey has been conducted in Summer 2014 among households of Kala Tonggu village $(n=50)$ and three villages in Hieu $(n=52)$, namely: Vi Glong $(n=17)$, Vi Chrinh $(n=24)$, and Vi Choong $(n=11)$. Between $18.9 \%$ and $61.5 \%$ of the total households in the villages were interviewed. Kala Tonggu was selected for this study because it was the only village in Bao Thuan participating in UN-REDD. The three villages in Hieu were randomly selected. However, Kala Tonggu village, alone consisted of more households than the three selected villages in Hieu commune combined. Therefore, a comparison between the two research sites was justified. Within each village, households were chosen through a systematic random sampling method. Households were asked about factual information as well as to comment on SES statements (measured with a Likert scale). Besides quantitative research, we gathered additional data from semi-structured expert interviews, policy documents and participant observation to supplement and triangulate the findings [48-55]. 
Due to time constraints, we could not employ in-depth ethnographic methods in both research sites. Therefore, participant observation in this study mainly entailed informal conversations with local households, joint excursions to natural forests and coffee fields, and attending community meetings in the village church (Kala Tonggu) and communal house (Hieu).

The operationalisation of this study is based on Figure 1. First, we identified the REDD+ activities in both case studies as well as the livelihood characteristics of the involved communities. Subsequently, our survey dealt with the governance systems and actors (including customary and formal institutions, and participation in REDD+), resource systems and units (including customary and formal forest classifications, and access to the natural forests after REDD+), and focal action situations and outcomes related to REDD+ (derived from household perceptions). Additionally, this study acknowledges the importance of the temporal dynamics of livelihoods. Livelihood change is, therefore, examined from a household's perspective over three or four periods: twenty years ago (before the introduction of formal forest management rules), ten years ago (before community-based forest management), five years ago (before REDD+), and at the time of research.

\subsection{Research Context}

Table 1 illustrates the research context in more detail. The households in Kala Tonggu were mainly coffee smallholders, whereas the households of Hieu were dependent on swidden agriculture. Hieu was also considerable poorer than Kala Tonggu in which $75 \%$ of the former and $12.5 \%$ of the latter lived in poverty (earning less than 400,000 VND or \$18 USD a month for rural area). Households in Kala Tonggu were considerably more integrated in the market economy, better connected to urban areas, and relatively less dependent on the natural forests than their counterparts in Hieu.

Table 1. Socio-economic characteristics of the research sites.

\begin{tabular}{|c|c|c|}
\hline Research Site: & \multirow{2}{*}{ Kala Tonggu $(n=50)$} & \multirow{2}{*}{ Hieu $(n=52)$} \\
\hline Dimension: & & \\
\hline REDD+ project & Multilateral (UN-REDD) & NGO (FFI-REDD+) \\
\hline Demographics & $\begin{array}{l}\text { - } 820 \text { people in } 196 \text { households (2013); } \\
\text { Bao Thuan commune consisted of } \\
6464 \text { people in } 1341 \text { households across } \\
11 \text { villages (2013). }\end{array}$ & $\begin{array}{l}\text { - } \quad 2783 \text { people in } 660 \text { households (2012); } \\
\text { - } \quad \text { Hieu consists of } 11 \text { villages; } \\
\text { Research has been conducted in Vi } \\
\text { Glong, Vi Chrinh and Vi } \\
\text { Choong village. }\end{array}$ \\
\hline Poverty rate & $12.5 \%(2013)$ & $75 \%(2012)$ \\
\hline Forestland & Natural forestland: 537 ha. & $\begin{array}{l}\text { Natural forestland: } 18,984 \text { ha of which } 2988 \\
\text { ha was degraded (2014). }\end{array}$ \\
\hline $\begin{array}{l}\text { Existing forest } \\
\text { management structure }\end{array}$ & $\begin{array}{l}\text { Kala Tonggu was involved in PFES, CBFM } \\
\text { (500 ha, Red Book since 2011) and forest } \\
\text { patrolling (Green Books). }\end{array}$ & $\begin{array}{l}\text { Only Vi Chrinh village owned a community } \\
\text { Red Book ( } 808 \text { ha, since 2008), some other } \\
\text { villagers had Green Books. }\end{array}$ \\
\hline Ethnicity & K'ho people formed the majority. & M'nam people formed the majority. \\
\hline General livelihood strategy & Mainly coffee smallholders. & Mainly swidden agriculturalists. \\
\hline Connectivity & $\begin{array}{l}\text { Relatively well connected to Dalat City. } \\
\text { Located besides a provincial road and Dong } \\
\text { Nai River }\end{array}$ & $\begin{array}{l}\text { Relatively isolated. Three-hour drive to Kon } \\
\text { Tum town-the provincial capital. }\end{array}$ \\
\hline
\end{tabular}

Source: [48-54].

\section{Results}

\subsection{Drivers of Change: REDD+}

UN-REDD mainly focused on Free Prior and Informed Consent (FPIC) activities and community carbon monitoring, whereas FFI-REDD+ also tried to reshape the forest governance of the commune by introducing CBFM and restoring the villages' customary forest boundaries [48,53]. Table 2 further 
elaborates on the conducted REDD+ activities in both research sites. The main difference between both projects is that UN-REDD employed a do-no-harm approach, meaning that it would not negatively affect local households, whereas FFI-REDD+ resembled an Integrated Conservation and Development Project (ICDP). Contrary to UN-REDD, FFI-REDD+ actively adopted a pro-poor approach, and included, besides carbon sequestration, other development goals in their planning.

Table 2. REDD+ activities in the research sites.

\begin{tabular}{|c|c|c|}
\hline Research Site: & \multirow{2}{*}{ Kala Tonggu } & \multirow{2}{*}{ Hieu } \\
\hline Dimension: & & \\
\hline Time period & $\begin{array}{l}\text { Pilot site of UN-REDD since } 2010 \text { (78 villages in } \\
\text { Lam Dong province were targeted). }\end{array}$ & $\begin{array}{l}\text { FFI-REDD+ started in } 2011 \text { and lasted until } 2014 \\
\text { in the commune. }\end{array}$ \\
\hline Targeted forest area & $\begin{array}{l}537 \text { ha in the village (Forest targeted for } \\
\text { protection and reforestation covered } 8954.98 \text { ha in } \\
\text { entire Bao Thuan commune). }\end{array}$ & 18,984 ha. \\
\hline REDD+ activities and funding & $\begin{array}{l}\text { Free Prior and Informed Consent (FPIC) } \\
\text { conducted: only three households voted } \\
\text { against UN-REDD and } 38 \% \text { did not vote } \\
\text { at all; } \\
\text { Workshops and awareness raising on } \\
\text { REDD+ in which the following components } \\
\text { were discussed: climate change, benefits of } \\
\text { participating in REDD+, REDD+ readiness } \\
\text { activities, livelihoods and REDD+, } \\
\text { forestland allocation, no consent for REDD+, } \\
\text { and infrastructure and development; } \\
\text { - Funding of carbon payments not clear. }\end{array}$ & $\begin{array}{l}\text { - Main aim was to comply with Climate, } \\
\text { Community and Biodiversity standards } \\
\text { (CCB) or Verified Carbon Standards } \\
\text { (VCS)-both are voluntary carbon markets, } \\
\text { - } \quad \text { Four main activities have been conducted: } \\
\text { - Stakeholder consultation and FPIC }(92.9 \% \\
\text { approval); } \\
\text { - Restructuring of forest governance } \\
\text { (establishment of CBFM); } \\
\text { - Carbon accounting; } \\
\text { - Environmental and social } \\
\text { impact assessments. }\end{array}$ \\
\hline Focus and approach & $\begin{array}{l}\text { Clear focus on carbon sequestration and } \\
\text { community carbon monitoring. } \\
\text { A do-no-harm approach. }\end{array}$ & $\begin{array}{l}\text { Resembled more an Integrated Conservation and } \\
\text { Development Project. Carbon sequestration was } \\
\text { one of the many development goals of } \\
\text { this project. }\end{array}$ \\
\hline REDD+ promotional video & https://goo.gl/AjwA3e & https://goo.gl/pUdN4t \\
\hline
\end{tabular}

Vietnam has been one of the original partner countries in the UN-REDD programme, since 2008. As part of Phase 1 of UN-REDD, two pilot districts in Lam Dong province were chosen to implement REDD+ activities. These activities had mixed outcomes (see: RECOFTC [56] for a full evaluation). The FPIC activities carried out in Kala Tonggu (amongst other villages) consisted of four principles: all communities living in and/or around the forest need to be involved; FPIC activities need to be proactively undertaken; the heterogeneity of the communities needs to be acknowledged; and FPIC processes need to be driven by relevant beneficiaries [53,54]. During the FPIC process, several potential opportunities and risks were identified, and communicated to the local communities (see Table 2). Representatives of the Food and Agriculture Organisation (FAO) and United Nations Development Programme (UNDP) proclaimed that, because REDD+ was not implemented in Lam Dong yet, the FPIC process has proven problematic. The people had little reason to reject REDD+, because the associated risks of REDD+ on local scale were unclear. Local people associated REDD+ mainly with receiving financial benefits for forest protection [55].

As for FFI-REDD+ in Hieu, the project focused on four components (as mentioned in Table 2). Stakeholder consultation involved capacity building of local authorities and agencies, as well as FPIC activities with local communities. FFI aimed to implement CBFM in 10 villages in Hieu, because Vi Chrinh already owned a Red Book for their community forest (808 ha) as result of a CBFM project by Japan International Cooperation Agency (JICA) in 2008. FFI-REDD+ wanted to restore around 18,000 ha of customary forestland in the commune. This resulted in a complicated negotiation process with provincial, district and commune government agencies and other stakeholders. This negotiation process is still on-going. FFI-REDD+ furthermore established carbon baselines and they conducted a carbon stock inventory in the commune. The communities in Hieu were not able to measure carbon 
by themselves yet, due to technical difficulties. However, they already established community forest management boards which patrolled the natural forest on a two-weekly or monthly basis, using GPS and skills acquired from the programme. Finally, environmental and social impact assessments were conducted. According to FFI, Hieu commune was estimated to lose 161.6 ha of forestland every year without the REDD+ project. According to this forecast, it would mean that in 30 years, the project site would lose 4688 ha of natural forestland in total [48,51].

\subsection{Livelihood Strategies and Capabilities}

While traditional livelihoods of the indigenous communities of Vietnam are often (wrongfully) characterised as fairly similar [57], there are considerable differences between the K'ho of Kala Tonggu and the M'nam of Hieu. Many K'ho communities located near the Dong Nai River (such as Kala Tonggu) have practiced wet rice cultivation for more than a century now. These communities grew a variety of wet rice both regular and glutinous. The M'nam, on the other hand, have traditionally practiced swidden agriculture. The swidden fields were farmed for 2-3 consecutive years before it was left for fallow. The fallow period would take up 7 to 10 years. Besides rice, the M'nam also cultivated maize, yam, banana, sugar cane, pineapple, watermelon and squash [58]. Another difference between the $\mathrm{K}^{\prime}$ ho in Kala Tonggu and the M'nam in Hieu was that the former converted to Christianity during colonial times, whereas the latter kept their animist beliefs. Therefore, the $\mathrm{K}^{\prime}$ ho were more or less well connected to "mainstream" society, whereas the M'nam remained relatively isolated.

The differences, as described above, can still be traced back today. The on-farm livelihood strategies of the $\mathrm{K}^{\prime}$ ho consisted of coffee growing (Coffea canephora) (98.0\%), wet rice cultivation $(98.1 \%)$, and livestock rearing $(28.0 \%)$. Besides coffee, these villagers did not grow any other cash crops. While currently the M'nam in Hieu also engaged in wet rice cultivation (98.1\%) and livestock rearing (51.9\%), a majority of the households still practiced swidden agriculture as a subsistence activity (73.1\%). Only a few households in Hieu grew coffee (11.5\%) and cash crops (11.5\%-mainly industrial cassava). The off-farm livelihood strategies of both research sites consisted of forest monitoring $(96.0 \%$ and $86.5 \%$ for Kala Tonggu and Hieu respectively), collecting Non-Timber Forest Products (NTFPs) $(50.0 \%$ and $57.7 \%$ ), and being a seasonal land worker $(26.0 \%$ and $9.6 \%)$. Additionally, $65.4 \%$ and $13.5 \%$ of the households in Hieu were involved in logging for housing and hunting respectively. Households in Kala Tonggu, on the other hand, claimed to completely abstain from participating in these activities. In terms of non-farm livelihood strategies, only a few households in both research sites were working in business and services, or for the local government.

The findings above indicate that the households of Kala Tonggu were notably more integrated in the market economy and also less dependent on the natural forests than their counterparts in Hieu. The average income of Kala Tonggu was therefore significantly higher than Hieu-2,500,000 VND (\$109.97 USD) a month for the former and 807,692 VND (\$35.53 USD) for the latter. The most common source of household income in Kala Tonggu came from coffee smallholding (averagely 20,479,592 VND (\$900.90 USD) a year), whereas most earnings in Hieu were derived from wet rice cultivation $(3,373,356$ VND or $\$ 148.95$ USD). The average contribution of forest monitoring to the total yearly household income in Kala Tonggu and Hieu has been minimal-935,111 VND (\$41.14 USD) and 609,189 VND (\$26.80 USD), respectively. These earnings came from forest contracting, PFES, and/or the REDD+ project funding. Even though the financial benefits of forest monitoring were small, most people still decided to participate in forest monitoring.

Table 3 explores the reasons why some households in both research sites did not conduct certain livelihood activities. Households in Kala Tonggu stated that they did not practice (potentially) environmentally degrading activities, such as logging for housing and selling, collecting NTFPs, and hunting and catching animals, because of government policy. The households of Kala Tonggu were less dependent on the natural forest, and thus more willing to adhere to government policy and regulations. This also explained the second most-mentioned reason why people did not engage in these activities: they considered it a personal choice. The same counted for intensive cultivation. It was 
clear that, for now, wet rice cultivation and planting coffee were sufficient for the villagers to maintain their livelihoods.

Table 3. Amount of households not having a particular livelihood (\%) and reasons why (\%) ${ }^{1}$.

\begin{tabular}{|c|c|c|c|c|c|c|c|}
\hline Kala Tonggu & $\begin{array}{l}\text { Per } \\
\text { Cent }\end{array}$ & $\begin{array}{l}\text { No Land or } \\
\text { Red Book }\end{array}$ & $\begin{array}{c}\text { Government } \\
\text { Policy }\end{array}$ & $\begin{array}{l}\text { Lack of Skills } \\
\text { and Knowledge }\end{array}$ & No Time & $\begin{array}{l}\text { Personal } \\
\text { Choice }\end{array}$ & $\begin{array}{l}\text { No/Other } \\
\text { Reason }\end{array}$ \\
\hline Swidden agriculture & 100 & - & - & - & - & - & 100 \\
\hline Intensive cultivation & 100 & 26.0 & - & 16.0 & 26.0 & $\underline{30.0}$ & $\overline{2.0}$ \\
\hline Logging for housing & 100 & - & $\underline{50.0}$ & - & - & $\overline{26.0}$ & 24.0 \\
\hline Logging for selling & 100 & - & $\overline{66.0}$ & - & - & 28.0 & 6.0 \\
\hline Coffee plantations & 2.0 & - & $\overline{-}$ & - & - & - & $\underline{100}$ \\
\hline Collecting NTFPs & 50.0 & - & $\underline{76.0}$ & - & - & 24.0 & - \\
\hline Hunting and catching animals & 100 & - & $\underline{44.0}$ & - & - & $\underline{44.0}$ & 12.0 \\
\hline \multicolumn{8}{|l|}{ Hieu } \\
\hline Swidden agriculture & 26.9 & $\underline{50.0}$ & - & - & - & - & $\underline{50.0}$ \\
\hline Intensive cultivation & 88.5 & $\overline{32.6}$ & - & $\underline{34.8}$ & - & - & $\overline{32.6}$ \\
\hline Logging for housing & 34.6 & - & $\underline{83.3}$ & $\overline{-}$ & - & - & 16.7 \\
\hline Logging for selling & 100 & - & $\underline{100}$ & - & - & - & - \\
\hline Coffee plantations & 88.5 & $\underline{52.1}$ & $\overline{10.9}$ & - & 10.9 & 10.9 & 15.2 \\
\hline Collecting NTFPs & 42.3 & $\overline{-}$ & $\underline{59.1}$ & - & 36.4 & & 4.5 \\
\hline Hunting and catching animals & 86.5 & - & 60.0 & - & 26.7 & 11.1 & 2.2 \\
\hline
\end{tabular}

Note: ${ }^{1}$ The percentages refer to the total amount of households not having this particular livelihood.

No land or Red Book was for many households in Hieu the most mentioned reason why they did not practice shifting and intensive cultivation, and coffee growing (only half of all households owned a Red Book as opposed to $84 \%$ in Kala Tonggu). No one mentioned that they could not conduct swidden agriculture because of government policy. It is condoned in Hieu, because of food insecurity and lack of livelihood alternatives. On the other hand, the capability to cut trees for housing and selling, collect NTFPs, and hunt and catch animals was hindered by government policy and regulations. Therefore, there was a growing awareness among households in Hieu that the natural forest was not free for everyone to exploit anymore.

Land tenure and government policy were the two most important factors influencing households' livelihood capabilities and strategies. Even though both communities mentioned that their livelihoods improved during the past twenty years (most important livelihood changes included: higher income, more stability and more food security), it can be inferred that the livelihood strategies and capabilities in both research sites were significantly different from each other. The coffee smallholders of Kala Tonggu were relatively well integrated in the market economy and depended far less on the natural forest, than the swiddeners of Hieu, who relied on the natural forest for subsistence. Additionally, the households in Hieu continued to participate in environmentally degrading livelihood activities, which could have serious implications for the success of REDD+ and carbon sequestration. It remains unclear how FFI-REDD+ will solve these interconnected problems related to food insecurity, deforestation and forest degradation in an inclusive and sustainable manner.

Based on the findings above, we reason that the less a community depends on the surrounding forest, the more likely REDD+ will succeed. Currently, the coffee smallholders of Kala Tonggu had little reason to engage in environmentally degrading livelihood activities due to their dependence on coffee smallholding and on-farm livelihood alternatives. This also explains why many households in Kala Tonggu did not vote during the FPIC process as they had initially little vested interest in REDD+ (Table 2). Furthermore, the direct financial benefits of the REDD+ activities have been minimal until now, even though most households participated in forest monitoring. It was expected in both research sites that REDD+ would eventually pay the households for their efforts. Therefore, both communities saw forest monitoring rather as a future investment than a livelihood strategy. This, however, could severely jeopardise the success of REDD+ if community expectations will not be met after carbon payments or in the near future. 


\subsection{Governance Systems and Actors}

Twenty years ago, the village patriarch and elderly were the most powerful institutions in the research villages-being in charge of land and forest management, conflict resolution, spiritual and social affairs, and supra-village relations and politics. Even though they were still present in the research villages, these customary institutions mainly served a ceremonial function now. Nonetheless, most households stated that customary institutions continued to play an important role. Village affairs were at the time of research handled by the village headman and secretary-formal government representatives on local level. They were governed by the Commune People's Committee (CPC), which was, on its turn, regulated by the District People's Committee (DPC) and higher level government authorities. Both UN-REDD and FFI-REDD+ did not involve customary institutions in their respective programmes, and, subsequently, further consolidated the power of formal institutions in the research sites.

The majority of households in both research sites claimed to be involved in REDD+. Only $14.8 \%$ of the villagers did not participate in REDD+ because of health or personal reasons. However, all interviewed villagers had heard about REDD+ and most households asserted that the Community Forest Management Boards (CFMBs), village headmen, patriarchs, government agencies and outside organisations involved them in REDD+ activities.

Figure 3 illustrates the forest governance systems in both research sites after REDD+ implementation. In Kala Tonggu, the central government through its REDD+ institutions-Vietnam REDD+ Office (VRO), REDD+ Network and the Sub-Technical Working Groups (STWGs)-was responsible for policy making, technical support and overall management (Figure 3a). Lam Dong province and its REDD+ taskforce were responsible for implementing REDD+ in Di Linh district. The District People's Committee (DPC), together with its Forest Protection Department (FPD), and in cooperation with Bao Thuan State Forest Enterprise (SFE) and Hieu Commune People's Committee (CPC), implemented REDD+ and CBFM in Kala Tonggu village. The CFMB of the village protected and monitored the community forest through its patrolling teams. This was done in cooperation with the commune forest rangers.

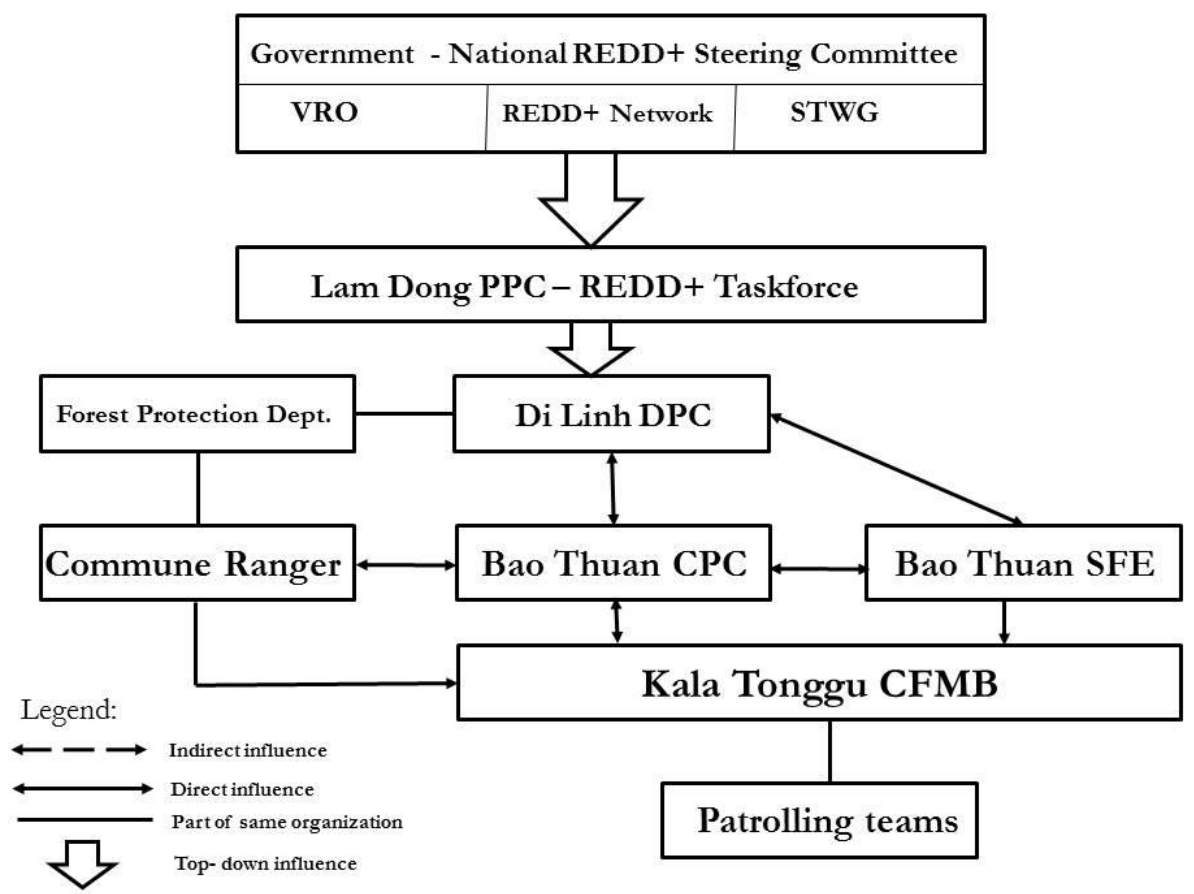

(a)

Figure 3. Cont. 


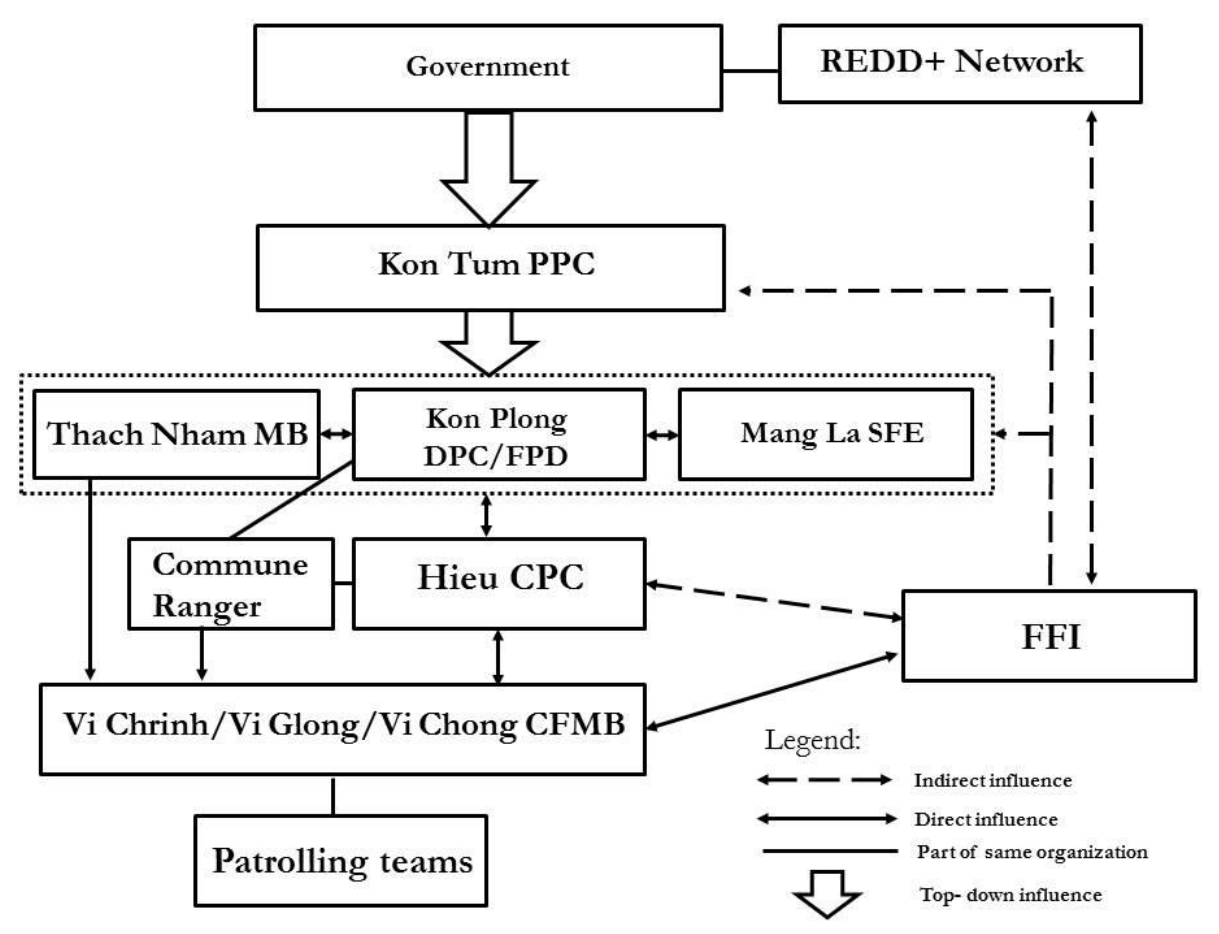

(b)

Figure 3. Forest governance and administration in: Kala Tonggu (a); and Hieu (b).

At the time of the research, Kon Tum province was not a UN-REDD province yet. Hence, the governance structure in Hieu was considerably different from Bao Thuan (Figure 3b). The central government and Kon Tum Province People's Committee (PPC) were responsible for general policy making and forest governance guidelines. Kon Plong DPC, Thach Nham Management Board (MB) and Mang La SFE owned most of the forestland in Hieu-3323.8 ha, 1814.3 ha and 12,516.9 ha, respectively. The DPC implemented its forest management policies and regulations through Hieu CPC, and was also responsible for forestland allocation. Thach Nham MB furthermore directly contracted households in the commune to monitor and patrol its natural forests for watershed protection. Each village in Hieu had a CFMB and corresponding patrolling teams. FFI's role in Hieu's forest governance was twofold. First, it paid and trained villagers to patrol and monitor the forests (unbroken double arrow). Second, it fulfilled a role as facilitator between the villages, Hieu CPC, Mang La SFE, Kon Plong DPC, Thach Nham MB, and Kon Tum PPC (broken arrows). The NGO aimed, through negations and capacity building, to persuade relevant actors to allocate forestland to local communities. FFI reported and shared its finding through the National REDD+ Network to improve REDD+ policies on the national level.

Based on Figure 3 and the survey results, three important differences can be found between Kala Tonggu and Hieu. First, UN-REDD did not change the forest governance of Kala Tonggu and Bao Thuan commune on a local level. On the national level, various new institutions and actors related to REDD+ were introduced, but, on the local level, it was mainly implemented through Kala Tonggu's existing forest governance infrastructure. This is in line with the findings of Trædal et al. [59] and McElwee [44], which conclude that market-based approaches, such as REDD+ and PFES, will most likely only reproduce existing institutional structures instead of restructuring them. On the contrary, FFI-REDD+ actively tried to reconstitute local forest governance structures by introducing CBFM. This resulted in the establishment of CFMBs and patrolling teams. The second difference is closely related to the first one: UN-REDD did not introduce new actors in Kala Tonggu village. Most REDD+ activities were carried out by either the DPC or CPC, and the REDD+ interlocutors only served the purpose of awareness raising and conducting FPIC activities. FFI, on the other hand, became an important actor 
in Hieu as it was not only financially and technically supporting local households to patrol and protect the community forests, but it was also directly influencing provincial, district and commune level agencies. Third, the role of power in Hieu was more pronounced than in Kala Tonggu. There were many land-related conflicts in Hieu between local households and Mang La SFE, between villages, and among households within a village. The SFE refused to give up its land for community forestry, whereas local households kept trying to enter and exploit it. Lack of land therefore caused a lot of tension in Hieu, and therefore, a vast majority of the households approved the efforts of FFI-REDD+ to reallocate natural forestland to the community (see also: To et al. [43]). This strongly resembles the second layer of the livelihood trajectory approach—the role of power [30]. Local households simply lacked the power and means to restore their, supposedly, customary boundaries. However, whether FFI is able to challenge and restructure existing power relations in Hieu commune remains open to question, as the negotiation process is still on-going at the time of writing this article.

The most important characteristic that both research sites had in common was lack of genuine community ownership. The communities did have a community Red Book or were in the process of having one. Moreover, the CFMBs were allowed to enter and patrol the forest, deal with violators, participate in afforestation activities, and respective communities could legally collect NTFPs in their community forest. However, according to households' statements related to governance systems and actors, the community was largely absent in the rule and decision making processes concerning forest management nor were they able to engage in commercial activities (selling their forestland or using it as collateral). Generally, the community had to adhere to the stipulated rules of the government in order not to have their Red Book revoked. Indeed, forest governance in Vietnam was far from being truly "decentralised" [43-45].

\subsection{Resource Systems and Units}

The resource system in Kala Tonggu village and Bao Thuan mainly consisted of degraded evergreen broad-leaved forest; deciduous forest; mixed bamboo and rattan forest; and coniferous forest, consisting of Pinus kesiya and Dipterocarpus obtusifolius trees. The community forest of Kala Tonggu was divided in medium (330 ha, accounting for 66\%) and poor evergreen broad-leaved forest (170 ha, 34\%). The latter was targeted for reforestation and rehabilitation [42]. Hieu's resource system, on the other hand, had a much higher level of biodiversity. It mainly consisted of subtropical evergreen broad-leaved forests. Some forest patches on its mountain peaks were mixed evergreen broad-leaved and subtropical coniferous forests containing genera such as Fokienia, natural Pinus, and Dacrydium. Hieu accommodated around 35 rare fauna and 12 rare flora species [48].

These findings reflect the types of exploited resource units, for both selling and subsistence, in both research sites. The households of Kala Tonggu primarily collected firewood, mushrooms, wild vegetables and bamboo shoots, and they caught or hunted for mice, birds and deer. Compared to Bao Thuan, the resource units in Hieu were much more varied. The collected NTFPs included: firewood, various types of mushrooms, bamboo shoots, Centella asiatica, honey, Anoectochilus setaceus and wild vegetables. Furthermore, local households caught mice, birds, ferrets, squirrels and frogs. People in Hieu, furthermore, revealed that they logged for a relatively high variety of tree species. Some of these species, such as Aquilaria crassna, Dalbergia tonkinensis Prain, and Erythrophleum fordii, are rare and listed on the International Union for Conservation of Nature (IUCN) Red List of Threatened Species as critically endangered or vulnerable [60].

The exploitation of the resource system was often influenced by formal and/or customary forest classifications. The former consisted of special-use (e.g., a national park), protection and production forests, whereas the latter included watershed protection, ghost, and shifting cultivation forests. Ghost forests are traditionally well-protected due to community spiritual beliefs and perceptions that they are guarded by powerful spirits and ghosts of deceased [43]. Furthermore, the community forest was usually part of (degraded) protection forest. Because most households in Hieu were informed by FFI-REDD+ where their community forest would be located, they already started patrolling and 
monitoring it. The households in the respective research sites were asked whether they were aware of the location, boundaries and respective size of aforementioned forest classifications (Table 4).

Table 4. Forest categories, mean estimated sizes (ha), perceived location (\%) and boundary (\%).

\begin{tabular}{|c|c|c|c|c|}
\hline & Forest Classification & & Kala Tonggu & Hieu \\
\hline \multirow{6}{*}{ Strictly formal } & \multirow{3}{*}{ Protection forest } & Estimated size & 500 & 204 \\
\hline & & Location & 56.0 & 51.0 \\
\hline & & Boundary & 48.0 & 39.2 \\
\hline & \multirow{3}{*}{ Special-use forest } & Estimated size & $?$ & $?$ \\
\hline & & Location & 4.0 & 25.5 \\
\hline & & Boundary & 4.0 & 17.6 \\
\hline \multirow{6}{*}{$\begin{array}{l}\text { Formal and } \\
\text { customary }\end{array}$} & \multirow{3}{*}{ Community forest } & Estimated size & 484.4 & 1524.8 \\
\hline & & Location & 64.0 & 78.4 \\
\hline & & Boundary & 58.0 & 58.8 \\
\hline & \multirow{3}{*}{ Shifting cultivation forest (individual plot) } & Estimated size & 0.5 & 5.9 \\
\hline & & Location & 98.0 & 88.2 \\
\hline & & Boundary & 98.0 & 76.5 \\
\hline \multirow{6}{*}{ Customary } & \multirow{3}{*}{ Watershed protection forest } & Estimated size & $?$ & $?$ \\
\hline & & Location & 8.0 & 35.3 \\
\hline & & Boundary & 8.0 & 17.6 \\
\hline & \multirow{3}{*}{ Ghost forest } & Estimated size & - & 15.8 \\
\hline & & Location & - & 88.2 \\
\hline & & Boundary & - & 74.5 \\
\hline
\end{tabular}

Note: "?" refers to "don't know".

In Kala Tonggu, households did not really recognise customary forest classifications anymore (Table 4). They classified their coffee fields as shifting cultivation forest because during the late 1990s they used slash-and-burn techniques to cultivate these fields. Especially, during this period, deforestation and forest encroachment were persistent problems in Kala Tonggu due to lack of clarity of forest classifications and boundaries. Prospective coffee smallholders would easily label forestland as production forest because the government supported them, through subsidies and loans, to grow coffee. This led to a high deforestation rate in the village and commune. Nowadays, the formal forest boundaries have been well established. However, some discrepancies can be observed in the findings. Even though all, but one, households claimed to be involved in forest monitoring, only $64.0 \%$ actually knew where their community forest was located. Households also often confused the protection forest for their community forest, because the estimated size of the former was 500 ha, which actually is the size of the latter. When households were asked where they collected their NTFPs, $52.0 \%$ claimed to do this in the protection forest, being a formally restricted area. While this amount is still relatively high, twenty years ago local households admitted to $\log (60.0 \%)$ and collect NTFPs $(88.0 \%)$ in the protection forest-signifying a positive change over time. Nowadays, households mainly collected NTFPs in the shifting cultivation forest $(70.0 \%)$ and community forest $(68.0 \%)$ - forest area where exploitation, to a certain degree, is legally allowed.

The situation in Hieu was different from Kala Tonggu (Table 4). Most households knew where their ghost forest was located $(88.2 \%)$, while only $51.0 \%$ knew the location of the protection forest. Those who claimed to know where these types of forest were located primarily exploited the protection forest for NTFPs (73.1\%) and timber $(46.2 \%)$, whereas the ghost forest has been left mostly untouched over the past 20 years. Only $11.1 \%$ of all households collected NTFPs in their ghost forest, whereas no one mentioned hunting or logging activities in this sacred forest. Protection forests and shifting cultivation forests were primarily perceived as forests for exploitation, whereas customary forests, such as ghost and watershed protection forests, were relatively well protected.

Both UN-REDD and FFI-REDD+ did not incorporate customary forest classifications in their respective programmes. For UN-REDD this has not been problematic as the households in Kala Tonggu did not recognise customary forest classifications anymore. To the contrary, in biodiversity rich Hieu customary forest classifications continued to play an important role. If REDD+ would 
only consider formal forest classifications, there is a high risk that it would fail in communes such as Hieu. These households were often uninformed about any formal arrangements. Therefore, in some cases, building upon formal arrangements alone would not be effective, and sometimes even counterproductive [60].

How did the resource systems and units of both communities change over time? Figure 4 illustrates changes in the perceived benefits from the natural forests over the past ten years in both research sites. The changes in Kala Tonggu were more or less clear: the villagers proclaimed that there were currently less derived benefits from the natural forest than ten years ago (Figure 4a). The results in Hieu, on the other hand, were mixed (Figure 4b). Households did not seem to agree whether the availability of NTFPs, fertile land and valuable wood species changed over time. A majority of the households in Hieu did see increased benefits derived from the natural forest in the form of protection against natural disasters and watershed protection. Concerning major drivers of change in derived benefits, both communities mentioned restrictive state policy, overexploitation of resource units, and decrease of forest area due to deforestation and illegal encroachment. These findings reveal that even biodiversity rich Hieu increasingly experienced problems of deforestation and forest degradation. It was for this reason that FFI-REDD+ selected Hieu as their project site [51].

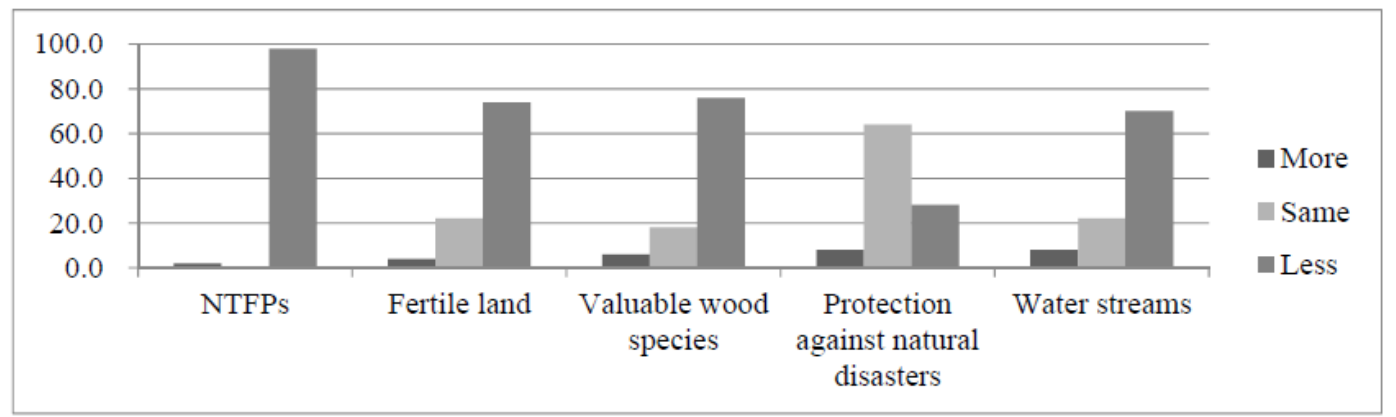

(a)

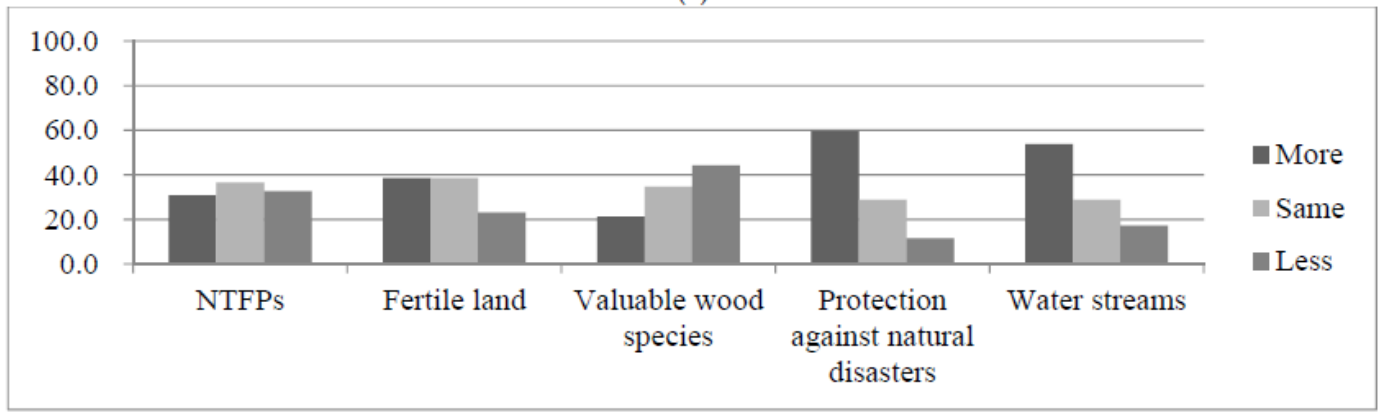

(b)

Figure 4. Benefits derived from the natural forest now as opposed to ten years ago (\%) in: Kala Tonggu (a); and Hieu (b).

To what extent has REDD+ thus far contributed to change in the resource systems of both research sites? More than $90 \%$ of the households in Kala Tonggu claimed that they had less access to the natural forest after REDD+ implementation. While these households perceived their community forest as a new classification, they did not attribute that to REDD+ as they already participated in CBFM prior to this programme. Around half of the households in Hieu proclaimed to have less access to the natural forest because of REDD+ (46.2\%), whereas others stated that it remained the same or even the opposite. Contrary to Kala Tonggu and with exception of Vi Chrinh, the establishment of community forests in Hieu can be directly attributed to FFI-REDD+. This raises an important issue: did CBFM, as introduced by FFI-REDD+, really restore the customary forest boundaries in Hieu, or was this another attempt by outside agents to reshape the M'nam's local forest landscape? 


\subsection{Focal Action Situations and Outcomes}

The focal action situations and socio-ecological outcomes of REDD+ implementation are hard to predict. In both research sites, carbon payments were yet to happen. This depends on the outcomes of the Conference of the Parties (COP) meetings (UN-REDD) and approval of CCB or VCS accreditation (FFI-REDD+). It is for this reason that households in both research sites were asked to comment on statements related to socio-ecological outcomes. This last part of the results section primarily concerns livelihood perceptions and consists of three interrelated dimensions: harvesting levels and information sharing after REDD+ (Figure 5); households' assessment of socio-ecological performance of REDD+; and the socio-ecological vulnerability context.
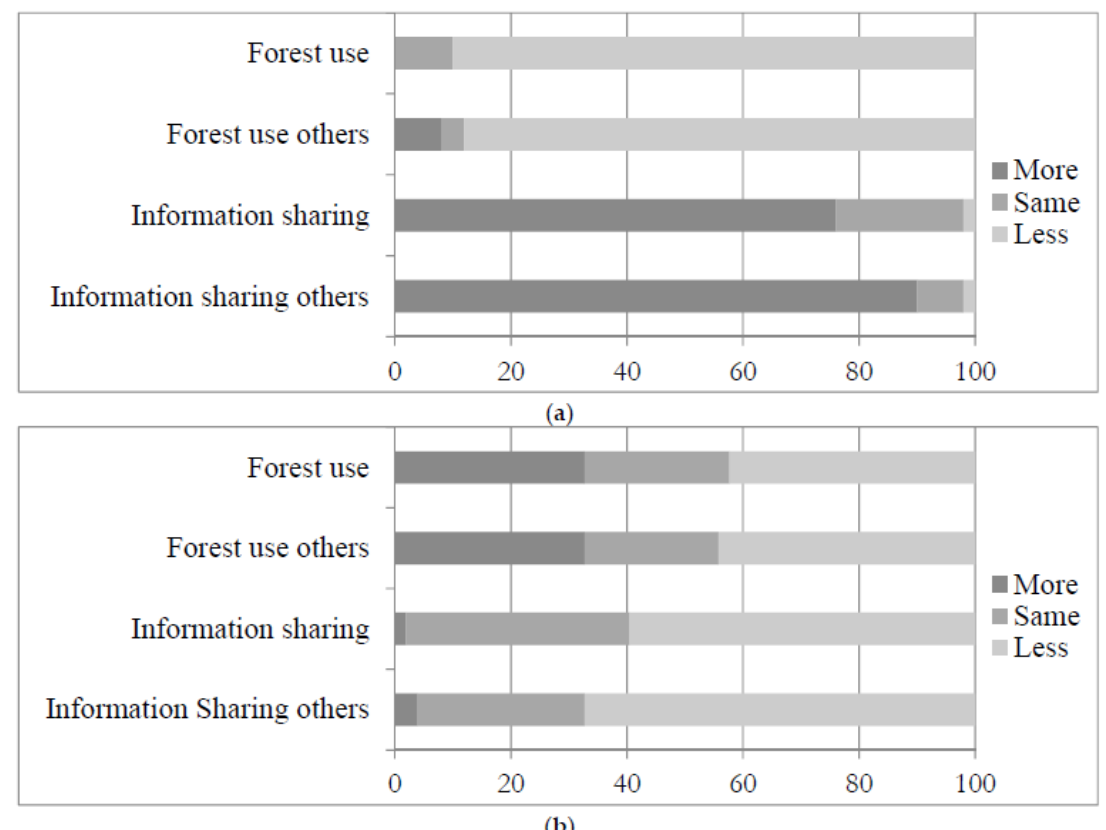

(b)

Figure 5. Harvesting levels and information sharing concerning forest use after REDD+ (\%) in: Kala Tonggu (a); and Hieu (b).

The harvesting levels of the households in Kala Tonggu were lower after REDD+ implementation as the villagers stated that they and others made less use of the natural forests. Furthermore, information sharing regarding forest management and exploitation had improved since REDD+. (Figure 5a) In Hieu, on the other hand, the villagers provided mixed statements regarding forest use of themselves and others (Figure 5b). Contrary to Kala Tonggu, households shared less information with each other after REDD+. This could be explained by the fact that households in Hieu were being educated on REDD+ at the time of research. New information on carbon, climate change and so on could have given them the feeling that they knew less about their surrounding forests; hence, they shared less information with each other.

Generally, most households claimed to be happy and supportive of REDD+. As mentioned in Section 4.2, they mainly perceived participating in REDD+ activities as an investment rather than livelihood. Households also claimed that they were consulted before REDD+ implementation and that local institutions, both formal and customary, were equally as supportive. Additionally, households confirmed that grievance mechanisms were in place. Other household statements regarding the social and ecological performance of REDD+, which were generally answered positively, included: fewer forestland-related conflicts; more derived benefits from the natural forest; REDD+ will improve the natural forest; and REDD+ is important in preventing natural disasters. However, both communities in the research sites asserted that REDD+ prevented them from making more use of the natural forest. 
As stated before, REDD+ restricted access to the natural forests of the local communities-this being more the case for Kala Tonggu than Hieu.

Most households in Kala Tonggu (64.0\%) disagreed with the statement that REDD+ would improve their financial situation as opposed to a majority of the villagers of Hieu (86.5\%) agreeing with the statement. Looking at the current marginal financial benefits of forest protection, this optimism could be a potential threat. Carbon payments have not been made yet; it might well be lower than expected. A study on REDD+ in Nepal has shown that carbon payments were barely enough to cover the transaction costs of the local communities [61]. Moreover, $70 \%$ of the households in Kala Tonggu disagreed with the statement that REDD+ gave them more livelihood possibilities. This figure was for Hieu completely the opposite: $80.8 \%$ of the villagers saw more possibilities after REDD+. FFI-REDD+ focused more on co-benefits (improved forest governance, forestland allocation, etc.), whereas UN-REDD primarily dealt with future carbon payments. This allowed the households of Hieu to see the benefits of REDD+ from a broader angle, and thus they saw more possibilities.

Temporal dynamics of livelihoods are important predictors of socio-ecological outcomes. These dynamics are not only influenced by agency but also by the socio-ecological vulnerability context. While households in Kala Tonggu were relatively financially well-off, they were particularly vulnerable to fluctuating global coffee prices. The global Robusta coffee crisis, during late 1990s, severely affected coffee smallholders in Vietnam, including the households of Kala Tonggu. Coffee smallholding in Vietnam has only been profitable again since 2006 [62]. Due to lack of social capital, many (prospective) indigenous coffee farmers also faced problems accessing loans or credit to establish or maintain their plantations. Besides facing problems with drought $(96.0 \%)$ and alcohol addiction in the village $(82.0 \%)$, this has been the second most-mentioned problem in Kala Tonggu village (82.0\%). Therefore, while households in Kala Tonggu might not enter the natural forest to sustain their livelihoods now, they could be forced to do otherwise if coffee smallholding becomes unprofitable again. This could be detrimental to the success of REDD+ and carbon sequestration through sustainable management of forests.

In Hieu, most households stated to be vulnerable to: alcohol addiction (100\%), flooding $(98.1 \%)$, drought $(78.8 \%)$, food insecurity $(73.1 \%)$, and poverty $(71.2 \%)$. The villagers, furthermore, faced problems with: lack of equipment for growing cash crops (88.5\%); accessing credit or loans $(82.7 \%)$; collecting NTFPs (69.2\%); and hunting or catching animals (51.9\%). The socio-ecological vulnerability context in Hieu is complex and multifaceted-influenced by both households' dependence on natural resources and the commune's growing integration in the market economy. Most likely, future carbon payments alone would not make these communities any less vulnerable, as the returns of REDD+ are predicted to be minimal. It is therefore important that the (future) co-benefits of REDD+ in Hieu also include: livelihood diversification, forestland allocation to households, and solutions to food insecurity in the commune (e.g., improved infrastructure for wet-rice cultivation or introducing sustainable forms of swidden agriculture).

\section{Discussion and Conclusions}

\subsection{Concluding Remarks and Contribution to the Literature}

This study has been an attempt to examine livelihood implications and household perceptions of REDD+ in the Central Highlands of Vietnam among forest-dependent communities. This is particularly important as global investment in forest commons, such as REDD+ continue to surge [7]. In Hieu, households had high expectations of REDD+ as they simply did not have any other on- or off-farm livelihoods alternatives. FFI-REDD+ also assisted them in securing their customary forestland rights. The coffee smallholders of Kala Tonggu, on the other hand, were less dependent on the natural forest, and they consequently expected fewer livelihood benefits related to REDD+. Nonetheless, also households in Kala Tonggu had certain (financial) expectations of UN-REDD. These expectations in both research sites could be detrimental to the success of REDD+ in the case that they are not met. 
Whether REDD+ can be successful very much depends on how it is implemented and how it relates to community livelihoods. In the case of Hieu, the co-benefits of REDD+ played a more important role than future carbon payments. Whether these benefits could incentivise people from not exploiting the natural forest remains unclear. The unpredictability of the livelihood outcomes of REDD+ also applies to UN-REDD in Kala Tonggu. Since local households in Kala Tonggu struggled to acquire loans and subsidies, the monetary benefits from REDD+ could be used for investment in households' coffee plots. However, nobody knows how these households will exploit the resource system and units once global coffee prices drop (see also: Cerbu et al. [63]). Within this context, the following three findings of this study could contribute to a better understanding of the livelihood implications of REDD+.

First, REDD+, or any large scale investment in natural resources for that matter, creates new opportunities for the communities involved. Often, in its initial phase, a new (power) vacuum is created, new alliances are formed and, simultaneously, with the advent of REDD+, new forest governance arrangements are introduced. In the case of FFI-REDD+, local communities were in the process of receiving forestland to restore their "customary" forest boundaries. On the other side of the coin, REDD+ also created new threats and risks. Households had less access to the natural forest after REDD+ and its financial benefits have been marginal so far. Moreover, the FPIC process often resembled REDD+ propaganda more than anything else. To prevent this, it is important that local and non-local actors form new alliances to fill in the voids caused by these global mechanisms to create new, but also stronger, forest governance systems, institutions, and livelihood alternatives. Within a REDD+ framework, local communities and households could make new claims to the natural forest, both in terms of ownership and management practices. However, there is a risk that new land claims are not always in line with REDD+ objectives. To and co-workers' [43] study in Hieu reveals that local communities made new land claims, using FFI-REDD+ to fulfil their local desire and need to cultivate cash crops. Therefore, within these new "glocal" alliances, REDD+ objectives need to be in line with community livelihood expectations and perceptions.

Second, the unintended livelihood effects of REDD+ are as important as the intended ones. The (potential) unintended effects in the case studies included: increasing food insecurity and vulnerability, deterioration of customary socio-ecological systems, and lack of genuine community ownership. There are various, often conflicting, systems influencing community livelihoods and capabilities. These systems include: customary and formal institutions and actors, traditional and formal ecological knowledge systems, and "western" and "indigenous" conceptions of local landscapes. Power and behaviour often manifest differently in each of these parallel systems, and therefore, the complex interplays among these systems need to be deciphered from a community or household perspective. Acknowledging the various systems and dynamics concerning natural resources and livelihoods allows policy makers and scholars to differentiate and study the intended and unintended effects of REDD+ (or any other large scale investment in natural resources) from a more holistic and interconnected perspective.

Third, the temporality of livelihoods needs to be understood more comprehensively than it has been to date $[29,63]$. On the one hand, it can be asserted that REDD+ had positive livelihood implications in the Central Highlands of Vietnam at the time of research-communities were generally happy with REDD+, received more benefits from forest protection, and participated through CBFM. On the other hand, these REDD+ programmes did not have a "Plan B". How could REDD+ remain sustainable and effective if coffee smallholding in Kala Tonggu becomes unprofitable again? Will REDD+ be able to provide a social safety net, or are local households forced to encroach REDD+ forests to sustain their livelihoods? Should we prevent households in Hieu from further integrating in the market economy? Moreover, how will REDD+ deal with swidden agriculture and environmentally degrading livelihood activities? Can swidden agricultural practices ever be compatible with REDD+? All of these questions should not only be answered from an agent-based and systems-perspective, but the temporal dynamics of livelihoods need to have a more prominent role in current scholarship on REDD+ and "the global land rush" for conservation. 


\subsection{Policy Recommendations}

Implementing REDD+ in a forest-dependent community involves various challenges. Building upon our research, the last part of this article provides several policy recommendations on both the macro- and micro-level. On macro-level, it is important that the SDGs are not simply perceived as goals that can be "traded off" with one another [64]. While SDG 13 (climate action) is important, it should not be achieved at the expense of SDG1 (poverty alleviation) or SDG2 (food security). Each goal has an intrinsic value on its own merits. On top of that, our research has shown that if issues such as food insecurity and lack of livelihood alternatives remain unsolved, carbon sequestration schemes are deemed to fail. Second, global and national attempts to combat climate change should be holistic and tied to measurable indicators. Steffen et al. [1] illustrate, by employing the concept of Anthropocene, how solutions to global environmental challenges could be approached more holistically. Third, it is of crucial importance that the rights of indigenous and local communities are sufficiently protected in a REDD+ scheme, as articulated by the United Nations Declaration on the Rights of Indigenous Peoples. (UNDRIP). FPIC should therefore be a compulsory process in REDD+ implementation. The methodology of FPIC also needs to be decided on a multilateral level in cooperation with indigenous peoples' rights organisations and other relevant stakeholders.

On micro-level, we differentiated three important dimensions towards successful REDD+ development: formal and customary forest boundaries and systems; formal and customary institutions; and temporal dynamics of livelihoods (Table 5). The policy recommendations in Table 5 are not meant to be exhaustive, and reflect the lessons learned and key conclusions of this study. They could prepare REDD+ implementers, government agencies, policy makers and private actors to adapt REDD+ to the local context. This to prevent unintended negative livelihood effects of REDD+, adapt REDD+ to changing socio-ecological conditions, and to form effective and inclusive partnerships with involved communities within a REDD+ framework.

Table 5. Policy recommendations towards successful REDD+ development on community level.

\begin{tabular}{|c|c|}
\hline Key Dimension: & Policy Steps and Key Questions \\
\hline $\begin{array}{l}\text { Formal and customary } \\
\text { forest boundaries } \\
\text { and systems }\end{array}$ & $\begin{array}{l}\text { How does REDD+ restructure local and indigenous landscapes? } \\
\text { - Identify the types of formal and customary forest boundaries and systems in a community. } \\
\text { - Comprehend the potential conflicts and synergies between formal and customary forest } \\
\text { management systems. } \\
\text { - Understand the forest management and exploitation practices of local communities in both } \\
\text { formal and customary forest classifications. } \\
\text { Integrate both customary and formal laws and rules related to forest management during } \\
\text { REDD+ implementation. } \\
\text { Adapt a REDD+ scheme to both formal and customary forest classifications and } \\
\text { tenure systems. }\end{array}$ \\
\hline $\begin{array}{l}\text { Formal and customary } \\
\text { institutions }\end{array}$ & $\begin{array}{l}\text { How does REDD+ restructure the existing forest governance infrastructure in a community? } \\
\text { - Identify all institutions, both customary and formal, in charge of village affairs and forestland } \\
\text { allocation. Do village patriarchs and elderly still matter, or did formal institutions already take } \\
\text { over decision-making processes in the village? } \\
\text { - Decipher power relations within a community. What roles do individual households have? } \\
\text { - Understand how outside actors, such as government institutions and the private sector, } \\
\text { influence local development and forest conservation in the REDD+ research site. } \\
\text { - Who invests in the REDD+ project and to what extent do local communities "own" the project? } \\
\text { Who decided and implemented the FPIC process? Did FPIC sufficiently include voices and } \\
\text { concerns from the community? } \\
\text { Identify the types of land-related conflicts within and between communities. Who is in charge } \\
\text { of resolving these conflicts? } \\
\text { REDD+ should incorporate both customary and formal institutions in its planning. The } \\
\text { diversity of households and actors, both within and outside the research site, should also be } \\
\text { taken into account. }\end{array}$ \\
\hline
\end{tabular}


Table 5. Cont.

\begin{tabular}{|c|c|}
\hline Key Dimension: & Policy Steps and Key Questions \\
\hline $\begin{array}{l}\text { Temporal dynamics } \\
\text { of livelihoods }\end{array}$ & $\begin{array}{l}\text { What kind of livelihood alternatives does REDD+ provide and can REDD+ cope with the } \\
\text { temporal dynamics of community livelihoods? } \\
\text { - Understand the main livelihood capabilities of members of a community. To what extent do } \\
\text { path dependency and other contextual factors influence current livelihood capabilities of } \\
\text { local households? } \\
\text { Measure to what extent local households are integrated in the market economy. Do local } \\
\text { households have access to loans and credit? Which factors prevent households from obtaining } \\
\text { financial capital? } \\
\text { Measure local households' dependence on the natural forest. Is this primarily based on } \\
\text { - } \\
\text { Idensistence or commercial activities? } \\
\text { - } \quad \text { Idew could REDD+ provide livelihood alternatives? } \\
\text { Investigate the desires, norms and needs of individual households. To what extent do these } \\
\text { individual preferences contribute to local development, and the conservation and sustainable } \\
\text { management of the forest commons? } \\
\text { Apprehend the socio-economic and ecological vulnerability context. In times of crisis, what } \\
\text { types of livelihood strategies do local households have at their disposal? } \\
\text { Set up a baseline on food insecurity among local households. When are local households } \\
\text { subjected to food insecurity and what are its proximate causes and underlying drivers? } \\
\text { Besides carbon sequestration, REDD+ could contribute to: livelihood diversification, } \\
\text { sustainable forms of swidden agriculture, forestland allocation to households and } \\
\text { communities, improving value chains of forest products, introducing sustainable timber } \\
\text { certification schemes, promoting community-based ecotourism, and so on. This makes a } \\
\text { community more resilient to internal and external shocks. }\end{array}$ \\
\hline
\end{tabular}

Acknowledgments: This study has been conducted at the Department of Geography and Resource Management of the Chinese University of Hong Kong, and it was supported by the Worldwide Universities Network Research Fund titled "Adopting REDD+ for Conservation, Sustainable Community Livelihood and Climate Change Mitigation" in 2013-2014. We also received financial support from the Department of Human Geography and Spatial Planning, and the University Library, both belonging to Utrecht University, to publish this article in this journal. We thank the three anonymous reviewers and Professor Annelies Zoomers for their invaluable feedback. We also thank Hue University of Agriculture and Forestry, Hue University, and Fauna and Flora International for hosting our research. Special thanks to Tran Nam Tu, Tran Huu Nghi (Tropenbos International) and Dang Thanh Liem (FFI). The views and opinions expressed in this article are those of the authors, and do not necessarily reflect the views and opinions of the people mentioned here.

Author Contributions: This research has been part of Mucahid Mustafa Bayrak's (M.M.B.) doctoral research at the Chinese University of Hong Kong under the supervision of Lawal Mohammed Marafa (L.M.M.). M.M.B. wrote the paper and conducted the research in Vietnam. L.M.M. provided feedback and contributed to the design of this study.

Conflicts of Interest: The authors declare no conflict of interest.

\section{References}

1. Steffen, W.; Grinevald, J.; Crutzen, P.; McNeill, J. The anthropocene: Conceptual and historical perspectives. Philos. Trans. A Math. Phys. Eng. Sci. 2011, 369, 842-867. [CrossRef] [PubMed]

2. United Nations Sustainable Development Goal 13. Available online: http://www.un.org/ sustainabledevelopment/climate-change-2/ (accessed on 5 August 2017).

3. Rahlao, S.; Mantlana, B.; Winkler, H.; Knowles, T. South Africa's national REDD+ initiative: Assessing the potential of the forestry sector on climate change mitigation. Environ. Sci. Policy 2012, 17, 24-32. [CrossRef]

4. Hoang, M.H.; Do, T.H.; Pham, M.T.; van Noordwijk, M.; Minang, P.A. Benefit distribution across scales to reduce emissions from deforestation and forest degradation in Vietnam. Land Use Policy 2013, 31, 48-60. [CrossRef]

5. Allan, J.I.; Dauvergne, P. The Global south in environmental Negotiations: The politics of coalitions in REDD+. Third World Q. 2013, 34, 1307-1322. [CrossRef]

6. Hauser, O.P.; Hendriks, A.; Rand, D.G.; Nowak, M.A. Think global, act local: Preserving the global commons. Sci. Rep. 2016, 6, 36079. [CrossRef] [PubMed] 
7. Zoomers, A.; Otsuki, K. Addressing the impacts of large-scale land investments: Re-engaging with livelihood research. Geoforum 2017, 83, 164-171. [CrossRef]

8. Bayrak, M.M.; Marafa, L.M. Ten years of REDD+: A critical review of the impact of REDD+ on forest-dependent communities. Sustainability 2016, 8, 620. [CrossRef]

9. Brundtland, G.H. Our Common Future: Report of the World Commission on Environment and Development; Oxford University Press: Oxford, UK, 1987.

10. Corbera, E.; Hunsberger, C.; Vaddhanaphuti, C. Climate change policies, land grabbing and conflict: perspectives from Southeast Asia. Rev. Can. Etudes Dev. 2017, 38, 297-304. [CrossRef]

11. Heynen, N.; McCarthy, J.; Prudham, W.S.; Robbins, P. Neoliberal Environments: False Promises and Unnatural Consequences; Routledge: New York, NY, USA, 2007.

12. Zoomers, A.; Van Westen, G.; Terlouw, K. Looking forward: Translocal development in practice. Int. Dev. Plan. Rev. 2011, 33, 491-499. [CrossRef]

13. Zoomers, A.; Van Westen, G. Introduction: Translocal development, development corridors and development chains. Int. Dev. Plan. Rev. 2011, 33, 377-388. [CrossRef]

14. Fairhead, J.; Leach, M.; Scoones, I. Green grabbing: A new appropriation of nature? J. Peasant Stud. 2012, 39, 237-261. [CrossRef]

15. Zoomers, A.; van Noorloos, F.; Otsuki, K.; Steel, G.; Van Westen, G. The Rush for land in an urbanizing world: From land grabbing toward developing safe, resilient, and sustainable cities and landscapes. World Dev. 2017, 92, 242-252. [CrossRef]

16. Schmidt-Thome, P.; Nguyen, T.H.; Pham, T.L.; Jarva, J.; Nuottimäki, K. Climate change in Vietnam. In Climate Change Adaptation Measures in Vietnam; Springer: Medford, MA, USA, 2015.

17. CIA World Factbook. Country Profile: Vietnam. Available online: https://www.cia.gov/library/ publications/the-world-factbook/geos/vm.html (accessed on 10 September 2017).

18. Asian Development Bank. Indigenous Peoples/Ethnic Minorities and Poverty Reduction in Vietnam; Asian Development Bank: Manila, Philippines, 2002.

19. De Haan, L.J. The livelihood approach: A critical exploration. Erdkunde 2012, 66, 345-357. [CrossRef]

20. De Haan, L.J.; Zoomers, A. Exploring the frontier of livelihoods research. Dev. Chang. 2005, 36, $27-47$. [CrossRef]

21. Sen, A. Commodities and Capabilities; Elsevier Science: Amsterdam, The Netherlands, 1985.

22. Chambers, R.; Conway, G.R. Sustainable Rural Livelihoods: Practical Concepts for the 21st Century; Institute of Development Studies at the University of Sussex: Brighton, UK, 1991.

23. Chambers, R. Poverty and livelihoods: Whose reality counts? Environ. Urban. 1995, 7, 173-204. [CrossRef]

24. Carney, D. Sustainable Rural Livelihoods: What Contribution Can We Make; Department for International Development: London, UK, 1998.

25. Scoones, I. Sustainable Rural Livelihoods: A Framework for Analysis; Institute of Development Studies at the University of Sussex: Brighton, UK, 1998.

26. Ellis, F. Household strategies and rural livelihood diversification. J. Dev. Stud. 1998, 35, 1-38. [CrossRef]

27. Bebbington, A. Social capital and development. In The Companion to Development Studies; Hoddor: London, UK, 2008.

28. De Haan, L.J.; Zoomers, A. Development geography at the crossroads of livelihood and globalisation. Tijdschr. Econ. Soc. Geogr. 2003, 94, 350-362. [CrossRef]

29. Sakdapolrak, P. Livelihoods as social practices-re-energising livelihoods research with Bourdieu's theory of practice. Geogr. Helv. 2014, 69, 19-28. [CrossRef]

30. De Haan, L.J. Livelihoods in development. Rev. Can. Etudes Dev. 2016, 38, 22-38. [CrossRef]

31. Leach, M.; Mearns, R.; Scoones, I. Environmental entitlements: Dynamics and institutions in community-based natural resource management. World Dev. 1999, 27, 225-247. [CrossRef]

32. Berkes, F. From community-based resource management to complex systems: The scale issue and marine commons. Ecol. Soc. 2006, 11, 45. [CrossRef]

33. Agrawal, A.; Gibson, C.C. (Eds.) Communities and the Environment: Ethnicity, Gender, and the State in Community-Based Conservation; Rutgers University Press: New Brunswick, NJ, USA, 2001.

34. De Bruijn, M.; van Dijk, H. Climate and society in Central and South Mali. In Sahelian Pathways. Climate and Society in Central and South Mali, 1st ed.; De Bruijn, M., van Dijk, H., Kaag, M., van Til, K., Eds.; African Studies Center: Leiden, The Netherlands, 2005; pp. 1-15. 
35. Holling, C.S.; Berkes, F.; Folke, C. Science, sustainability and resource management. In Linking Social and Ecological Systems; Cambridge University Press: Cambridge, UK, 1998.

36. Ostrom, E. A diagnostic approach for going beyond panaceas. Proc. Natl. Acad. Sci. USA 2007, 104, 15181-15187. [CrossRef] [PubMed]

37. McGinnis, M.D. Building a Program for Institutional Analysis of Social-Ecological Systems: A Review of Revisions of the SES Framework; Workshop in Political Theory and Policy Analysis: Bloomington, IN, USA, 2010.

38. Ostrom, E.; Cox, M. Moving beyond panaceas: A multi-tiered diagnostic approach for social-ecological analysis. Environ. Conserv. 2010, 37, 451-463. [CrossRef]

39. Gallopín, G.C. Linkages between vulnerability, resilience, and adaptive capacity. Glob. Environ. Chang. 2006, 16, 293-303. [CrossRef]

40. Adger, W.N. Vulnerability. Glob. Environ. Chang. 2006, 16, 268-281. [CrossRef]

41. Ostrom, E. A General framework for analyzing sustainability of social-ecological systems. Science 2009, 325, 419-422. [CrossRef] [PubMed]

42. Anderies, J.M.; Janssen, M.A.; Ostrom, E. A framework to analyse the robustness of social-ecological systems from an institutional perspective. Ecol. Soc. 2004, 9, 18. [CrossRef]

43. To, P.; Dressler, W.; Mahanty, S. REDD+ for Red Books? Negotiating rights to land and livelihoods through carbon governance in the Central Highlands of Vietnam. Geoforum 2017, 81, 163-173. [CrossRef]

44. McElwee, P.D. Payments for environmental services as neoliberal market-based forest conservation in Vietnam: Panacea or problem? Geoforum 2012, 43, 412-426. [CrossRef]

45. Sikor, T.; Nguyen, T.Q. Why may forest devolution not benefit the rural poor? Forest entitlements in Vietnam's central highlands. World Dev. 2007, 35, 2010-2025. [CrossRef]

46. Castella, J.C.; Boissau, S.; Thanh, N.H.; Novosad, P. Impact of forestland allocation on land use in a mountainous province of Vietnam. Land Use Policy 2006, 23, 147-160. [CrossRef]

47. Dam, B.V.; Catacutan, D.C.; Ha, H.M. Importance of national policy and local interpretation in designing payment for forest environmental services scheme for the Ta Leng River Basin in Northeast Vietnam. Environ. Natl. Res. Res. 2014, 4, 39-53. [CrossRef]

48. Dang, T.L.; Trinh, N.T. Description of Communities Participating in the EU-REDD+ Project in Kon Plong District, Kon Tum Province, Vietnam, Technical Report No. 1; Fauna and Flora International: Kon Tum, Vietnam, 2012; unpublished.

49. Forwet. Survey Report on Forest Contracts to Da Sar Commune and Forestland Allocation to Communities in Bao Thuan and Phu Hoi Communes, Lam Dong Province; Research Center for Forests and Wetlands: Ho Chi Minh City, Vietnam, 2013.

50. Regulation on Organisation, Management, Activities and Benefit Sharing in the Community Forest of Kala Tonggu Village, Bao Thuan Commune; Commune People's Committee (CPC) of Bao Thuan: Di Linh, Vietnam, 2012; unpublished.

51. Dang, T.L. Personal Communication; Fauna and Flora International: Cambridge, UK, 2014.

52. Fauna and Flora International (FFI). Policy Bulletin No. 3-REDD+ Pilot Project: Key Lessons Learned for Expanding the National REDD+ Model and Its Implementation; FFI: Cambridge, UK, 2015.

53. The United Nations Collaborative Programme on Reducing Emissions from Deforestation and Forest Degradation (UN-REDD). Manual for Interlocutors: To Conduct FPIC Village Consultation Meetings; UN-REDD: Hanoi, Vietnam, 2012; Available online: http:/ / www.unredd.net/index.php?option=com_docman\&task= doc_details\&gid=7674\&Itemid=53 (accessed on 5 August 2017).

54. The United Nations Collaborative Programme on Reducing Emissions from Deforestation and Forest Degradation (UN-REDD). UN-REDD Viet Nam Phase II Programme: Operationalising REDD+ in Viet Nam; UN-REDD: Hanoi, Vietnam, 2013.

55. United Nations Development Programme (UNDP); Food and Agriculture Organization of the United Nations (FAO). Personal Communication; UNDP \& FAO: Hanoi, Vietnam, 2013.

56. The Center for People and Forests (RECOFTC). Evaluation and Verification of the Free, Prior and Informed Consent Process under the UN-REDD Programme in Lam Dong Province, Vietnam; RECOFTC: Bangkok, Thailand, 2010.

57. Salemink, O. The Ethnography of Vietnam's Central Highlanders: A Historical Contextualization 1850-1990; RoutledgeCurzon: London, UK, 2003.

58. Hickey, G.C. The Highland People of South Vietnam: Social and Economic Development, 1st ed.; Rand Corporation: Santa Monica, CA, USA, 1967. 
59. Traedal, L.T.; Vedeld, P.O.; Pétursson, J.G. Analyzing the transformations of forest PES in Vietnam: Implications for REDD+. For. Policy Econ. 2016, 62, 109-117. [CrossRef]

60. Bayrak, M.M.; Marafa, L.M. The role of sacred forests and traditional livelihoods in REDD+: Two case studies in Vietnam's Central Highlands. In Shifting Cultivation Policies: Balancing Environmental and Social Sustainability, 1st ed.; Cairns, M., Ed.; Centre for Agriculture and Bioscience International (CABI): Wallingford, UK, 2017; in press.

61. Maraseni, T.N.; Neupane, P.R.; Lopez-Casero, F.; Cadman, T. An assessment of the impacts of the REDD+ pilot project on community forests user groups and their community forests in Nepal. J. Environ. Manag. 2014, 136, 37-46. [CrossRef] [PubMed]

62. Marsh, A. Diversification by Smallholder Farmers: Viet Nam Robusta Coffee. Agricultural Management, Marketing and Finance Working Document; Food and Agriculture Organization of the United Nations (FAO): Rome, Italy, 2007.

63. Cerbu, G.A.; Sonwa, D.J.; Pokorny, B. Opportunities for and capacity barriers to the implementation of REDD+ projects with smallholder farmers: Case study of Awae and Akok, Centre and South Regions, Cameroon. For. Policy Econ. 2013, 36, 60-70. [CrossRef]

64. Holden, E.; Linnerad, K.; Banister, D. The Imperatives of sustainable development. Sustain. Dev. 2016, 25, 213-226. [CrossRef]

(C) 2017 by the authors. Licensee MDPI, Basel, Switzerland. This article is an open access article distributed under the terms and conditions of the Creative Commons Attribution (CC BY) license (http://creativecommons.org/licenses/by/4.0/). 